This item was submitted to Loughborough's Research Repository by the author.

Items in Figshare are protected by copyright, with all rights reserved, unless otherwise indicated.

\title{
Academic travel from Cambridge University and the formation of centres of knowledge, 1885-1954
}

PLEASE CITE THE PUBLISHED VERSION

http://dx.doi.org/10.1016/j.jhg.2007.11.006

\section{PUBLISHER}

(C) Elsevier

VERSION

AM (Accepted Manuscript)

\section{PUBLISHER STATEMENT}

This work is made available according to the conditions of the Creative Commons Attribution-NonCommercialNoDerivatives 2.5 International (CC BY-NC-ND 2.5) licence. Full details of this licence are available at: https://creativecommons.org/licenses/by-nc-nd/2.5/

\section{LICENCE}

CC BY-NC-ND 2.5

\section{REPOSITORY RECORD}

Jons, Heike. 2019. "Academic Travel from Cambridge University and the Formation of Centres of Knowledge, 1885-1954”. figshare. https://hdl.handle.net/2134/5924. 


\title{
Academic travel from Cambridge University and the formation of centres of knowledge, 1885-1954
}

Heike Jöns

\section{Please cite this paper as follows:}

Jöns, H (2008) Academic travel from Cambridge University and the formation of centres of knowledge, 1885-1954, Journal of Historical Geography, 34(2), pp.338-362, ISSN: 03057488. DOI: $10.1016 / j . j h g .2007 .11 .006$

\begin{abstract}
This paper draws the attention to academic travel as a key issue in the geographies of knowledge, science and higher education. Building upon recent work in science studies and geography, it is argued that academic travel reveals the wider geography of scientific work and thus of the knowledge and networks involved. By examining academic travel from Cambridge University in the period 1885 to 1954 , the study clarifies its role in the development of Cambridge as a modern research university, the emergence of global knowledge centres elsewhere and the development of an Anglo-American academic hegemony in the twentieth century. Using unpublished archival data on all recorded applications for leave of absence by Cambridge University Teaching Officers, it is further explored how the global geographies of academic travel varied among different types of work, thereby exposing distinct hierarchies of spaces of knowledge production and sites of study.
\end{abstract}

Keywords: academic travel, knowledge production, geographies of science, transnational networks, higher education, Cambridge University

Running Head: Academic travel from Cambridge University 


\section{INTRODUCTION}

Academic travel can be regarded as an important process in the production and exchange of scientific knowledge and the formation of scholarly networks across the globe. ${ }^{1}$ It may be necessary for accessing field sites, libraries and archives when producing new scientific arguments, it may contribute to the dissemination and evaluation of scientific knowledge in different places, and it may also play an important role for informal contacts, exchanges and collaborations between distant laboratories and academics. In his seminal book Science in Action, Bruno Latour pointed out that the circular process of going away, crossing the paths of other people and returning enables scientists to perform at least three tasks: first, to mobilise new and often unexpected resources for knowledge production; second, to test the value of newly-constructed truth claims in different settings; and, third, to spread arguments and facts in time and space. ${ }^{2}$ Academic travel from Cambridge University, as studied in this paper, precisely resembles the circular form of mobility and mobilisation that Latour considers to be constitutive in the production of scientific knowledge at a variety of scales. ${ }^{3}$ In this context, academic travel can be defined as physical journeys by academics for the purpose of research, lecturing, visiting appointments, consulting and other professional tasks. These journeys may last between a few days and a couple of years, but they are in principle temporary absences with the travelling academics intending to return to their academic institution.

Geographers and historians of science have devoted considerable attention to scientific travel in the ages of modern discovery and exploration. ${ }^{4}$ However, surprisingly little is known about the nature of academic travel at modern research universities as they emerged in the nineteenth century. ${ }^{5}$ While David Livingstone concluded from historical case studies that 'the growth of scientific knowledge has been intimately bound up with geographical movement', the ways in which academic travel contributed to the production of knowledge at modern universities have yet to be explored. ${ }^{6}$ In a recent review of the field, Richard Powell suggests 
that '[a]n arena in which there is great potential for future contributions by geographers of science is around discussions of travel, instrumentation, and metrology' as '[i]t is in this work that the competing understandings of the spatiality of science have undertaken fecund interaction'. ${ }^{7}$ Considering the multiple meanings of travel for academic work, the study of academic travel in fact appears to be a central issue for histories and geographies of knowledge, science and higher education. ${ }^{8}$ Geographical movements of academics, which are at least partly motivated by their work, contribute to the production and dissemination of ideas, arguments and facts and thus to the alteration of existing knowledge in the places concerned. ${ }^{9}$ Accordingly, Ronald Barnett and Alison Phipps maintain that academic travel 'indexes more than physical journeys, and physical journeys themselves point to changes in conceptions of knowledge and ideas'. ${ }^{10}$ Katrina Dean addresses the material effects of academic travel as well, arguing that 'processes of circulation like travel produce scientific knowledge and change geographies'. ${ }^{11}$ As such, studying geographical movements of academics helps to reveal the wider geographies of academic work and intellectual exchange, and of the knowledge and networks involved, in at least five ways.

First, studying academic travel helps to explore the important question of where academic knowledge was produced. Crucial here are inquiries about the places deemed interesting or resourceful enough to contribute to knowledge production and those neglected as sites of study and thus not entering the agendas of research and teaching. Second, academic travel is inextricably linked to the history of geographical thought since all travellers, as Michael Heffernan put it, 'were contributing to a synthesizing geographical consciousness in which newly acquired knowledge about the physical and human attributes of particular places and regions gleaned from other disciplines was drawn together under the banner of geography'. ${ }^{12}$ Mapping the destinations of academic travel thus also provides an idea about the making of geographical knowledge circulating within and beyond the academy. 
Third, by identifying clusters of visitors to certain places, the study of academic travel helps to map the hierarchies of centres of knowledge production and dissemination. Which places attracted most academics and for what reasons? For example, destinations of research travel will have promised valuable resources (and might have been exploited for research). Knowledge was transferred, discussed and exchanged in the context of visiting appointments, invited lectures and conference travel, while the places of academic consulting indicate where scientific expertise was sought by governments, companies and other bodies. The geographies of academic travel for different types of work thus expose global power-relations within science and higher education. Fourthly, they also promise further insights into the relationship between science and politics. Mainly a question of data availability, the few studies conducted on geographical and topical patterns of modern academic travel have relied on sponsorship programmes. These programmes emerged in the course of the nineteenth and twentieth centuries and often contributed to the development of nationally orientated systems of academic patronage. ${ }^{13}$ Analysing the geographical destinations and topical foci of French international field work funded by the Comité des Travaux Historiques (founded in 1834) and the Service des Missions (founded in 1842) in the period 1830 to 1914, Michael Heffernan argued that the travelling scholars' preference for western Europe and the Mediterranean basin was the result of a 'compromise between intellectual curiosity, practical expediency and the political judgements of well-briefed scientists and scholars under the direct control of government officials and civil servants'. ${ }^{14}$ This argument raises questions about the ways in which state authorities, imperial or other political interests have influenced academic travel from modern universities and thus the production and trade of knowledge at institutions of higher education. ${ }^{15}$

Fifth, the study of academic travel draws attention to the wider networks that sustain modern universities. Institutional histories of universities rarely follow the complex external 
linkages constitutive of research and teaching. However, these linkages - of which circular movements of academics represent but one dimension - provide important information on the extent and nature of the internationalisation of higher education and the wider political, cultural and intellectual meaning of universities. ${ }^{16}$

In this paper, I begin to explore these larger questions by analysing travel cultures of Cambridge academics in the period 1885 to 1954 . In the late nineteenth and early twentieth centuries, when Britain was the leading world power, Cambridge University attracted 'talent from every corner of the globe'. As Christopher Brooke argues, this was 'partly because a prejudice was abroad - not often related to the facts - that Cambridge was a distinguished university'. ${ }^{17}$ Essentially, the university experienced a 'transition to a major international centre of scholarly and scientific teaching and research' from the 1880s to the 1950s, which makes it a suitable focus for analysing the role of academic travel in the formation of the modern university. ${ }^{18}$ The analysis is based on a database of all recorded applications for leave of absence by Cambridge University Teaching Officers, who include professors, readers, lecturers, demonstrators, assistant lecturers and a few other academic posts. This database was created from individual entries in the minute books of the General Board of Studies (since 1926 the General Board of the Faculties), which has been the body responsible for all academic affairs at Cambridge since 1882. Providing information on the date of the application, the name, position and subject of the applicant, and, less frequently, on the period, purpose and destination of the planned leave of absence, this unique data set allows for the analysis of both individual itineraries and global patterns of academic travel in different types of work. ${ }^{19}$

This paper focuses on the global geographies of academic travel by interpreting geographical patterns of physical journeys by Cambridge academics (as far as they can be reconstructed from the archival data). Identifying the places involved in academic travel from 
Cambridge reveals as much about the making of 'geography', or a 'geographical consciousness', in Britain and Europe at the time as it tells about the intellectual history of Cambridge University in the late nineteenth and early twentieth centuries. Other epistemological and ontological questions of academic travel, including the metaphorical movement 'across the boundaries of fields of knowing' and an academic's 'personal journey of change, challenge, and even struggle', will inform the analysis as they inevitably intersect with geographical movement. ${ }^{20}$ However, rather than looking at the results of specific journeys, this essay discusses the nature and wider meaning of academic travel for Cambridge University and the global geographies of knowledge, science and higher education.

By examining transnational linkages of an individual academic institution, this analysis complements national perspectives on the study of science. ${ }^{21}$ The maps presented in this paper, however, display travel destinations by country as this geographical scale was most frequently represented in the sources (compared, for example, to places, cities and supranational regions), thus allowing for meaningful comparisons. The period studied here is the seventy years after Cambridge academics were first required to apply for leave of absence during term time. While the starting point is thus defined by the institutionalisation of academic travel at Cambridge University and the related availability of comparable travel data, the end of this period coincides with the end of the first post-war decade, which saw the disintegration of the British Empire and the beginning of commercial air travel. The dawning age of commercial air transport provides particular good reasons for ending the analysis after a period of seventy years as this brought about revolutionary changes for individual travel behaviour. $^{22}$ The chosen period also enables critical reflection on an argument in the history of cross-boundary science, which associates the period under study with the transition from a prevailing nationalism to a stronger internationalism said to have emerged before World War One and eventually flourished after World War Two. ${ }^{23}$ 
Drawing upon recent work in the history and geography of science, this study has four broader aims. First, by mapping the global 'reach' of Cambridge University, it strives to reveal the wider geography of academic and geographical knowledge circulating between different places of knowledge production at the time. Second, it explores the role of academic travel for the emergence of Cambridge as a modern research university. Third, it investigates the ways in which the circular flows of academics fostered the formation of knowledge centres elsewhere. Fourth, it examines how the global geographies of academic travel varied among different types of work.

\section{A HISTORY OF PROFESSIONALISATION}

Cambridge University is the younger of England's two ancient universities. Like Oxford, it is characterised by a loose confederation of faculties, colleges and other bodies, which has led to multiple commitments of its academics to research, teaching and administration. ${ }^{24}$ The foundation for a successful research university was laid in the late nineteenth century when a new system of college taxation, recommended by the University Commission of 1872 , alongside large private endowments, allowed for significant investments in new posts and facilities in the Sciences. ${ }^{25}$ This included the foundation of the renowned Cavendish Laboratory in 1870 and was manifested in the development of new scientific fields such as electronics and computer technology, nuclear physics, biochemistry and genetics. ${ }^{26}$

Far beyond Cambridge, this period was associated with the rise of new subjects, professorships, laboratories, journals and supporting institutions. Through the foundation of scientific associations, the emergence of international conferences and the implementation of research awards such as the Nobel Prize (granted from 1901 onwards), academic networks were promoted well beyond the nation-state, while comprehensive university and college reforms marked important steps in the professionalisation of higher education and research. ${ }^{27}$ 
In Cambridge, the new University Statutes of 1882 introduced the requirement for professors and readers to 'be resident throughout full term time'. ${ }^{28}$ These new regulations specified the limits of the area within which professors and readers were required to live (defined by distance from the university church) and how often they had to be available to students and colleagues in Cambridge. For any period in which they were not able to adhere to the strictly defined rules of residence, professors and readers had to get permission from the General Board. This was done by applying for 'leave of absence' that freed an academic, for the period specified in the application or agreed by the General Board, from the duties as a University Teaching Officer, including residence requirements. ${ }^{29}$ Therefore, the data on applications for leave of absence contains all absences from university duties during full term time (whether parts or all of it), the majority of which involved travelling and thus physical absence from Cambridge. As Cambridge academics remained free to travel during vacations, the presented data are far from providing a complete picture of their travels. They do, however, offer unique insights into the destinations of academic travel that would otherwise remain unknown. More importantly, it can be assumed that the data cover most journeys exceeding the duration of three months as this is the length of the Long Vacation. Absences from Cambridge of over three months covered at least parts of full term time and thus required an application for leave of absence. ${ }^{30}$

In this section, data on all recorded applications for leave of absence are discussed, including absences to represent the university in parliament, personal affairs, war service, or ill health. In the remaining sections, the focus is on applications for academic leave of absence (in short, 'academic leave') for research, lecturing, teaching, consulting, administration and other professional tasks. A particular emphasis is placed on the development of 'sabbatical' leave, understood as a periodically granted academic leave providing university teachers an opportunity for self-improvement 'with full or partial compensation following a designated 
number of years of consecutive service'. ${ }^{31}$ Freed from any teaching and administrative responsibilities, or rather obliged effectively to give up these duties in Cambridge in order to receive the full stipend, academics on sabbatical leave were to some extent free to decide how to use their time for 'professional, personal and creative growth', but it often involved the concentration on study and research, writing, travelling or visiting appointments. ${ }^{32}$ Since the first system of sabbatical leave had been established at Harvard University in 1880, a focus on research and self-improvement, to a lesser extent also on curriculum development and service to the discipline or academic institution, has been considered 'as an investment in the future of the institution granting [the leave] ${ }^{33}$ Sabbatical leave can thus be regarded as an important part of the research culture at a modern university. In Cambridge, this research culture slowly began to emerge through a series of university reforms in the late nineteenth century, which, among other things, introduced the first regulations on the residence, accessibility and leave of absence of professors and readers.

In the seven decades after the institutionalisation of academic travel at Cambridge, the annual number of applications for leave of absence grew considerably, if not steadily (figure 1). In the period up to World War One, the General Board, governing the academic affairs of about 100 university professors, readers and lecturers (figure 2A), received up to ten applications for leave of absence per year; less than half of them for academic reasons. Accordingly, the idea of spending a sabbatical leave abroad was not well established in Cambridge at the time. When William Emery Barnes, Hulsean Professor of Divinity, was anxious on the grounds of his wife's health 'to avoid next winter in Cambridge' and to accept the offer by the Bishop of Gibraltar to do a chaplaincy in Malta from November 1912 to April 1913, Francis Crawford Burkitt, Norrisian Professor of Divinity, supported him with the following letter: ${ }^{34}$ 
From something said yesterday by the [Regius Professor of Divinity] I gathered that you feared some of your colleagues didn't approve of your winter 'holiday', so I write to assure you that I personally do approve of your plan. ... I really think that a change of scene, so long as fairly adequate stop-gaps are forthcoming, is good for work generally, and so in the long run your temporary absence will not hurt theological teaching in the University. The American Professors gain greatly by their 'sabbatical year'. Besides, as I understand, you will be having pastoral experience and will be doing theological literary work during your absence, such as you would not have the opportunity for if you had been absent from illness, or had been [Vice-Chancellor] ... Best wishes for a very profitable as well as enjoyable holiday! ${ }^{35}$

Written at a time when at least 28 institutions of higher education in the United States had established systems of sabbatical leave, Burkitt's repeated use of the word 'holiday' reveals an attitude that seeks to neatly separate duty in Cambridge from leisure abroad. ${ }^{36}$ Thus Barnes felt the need to further elaborate on his plans in a second letter, reassuring the General Board that he would not be 'out of reach' for his colleagues since '[t]he post to Malta takes four days. 37

[Figure 1 about here]

During World War One, a considerable number of Cambridge academics were engaged in war-related services, which underlines the great significance of academic knowledge and expertise in times of war. ${ }^{38}$ Sir Arthur Quiller-Couch, renowned Professor of English Literature, served as a recruitment officer in the county of Cornwall to raise a force of pioneers. In May 1918, Quiller-Couch's second application for leave of absence was the first application not granted in more than 15 years. In the opinion of the General Board, the work he proposed to conduct in Cornwall 'was not sufficiently connected with the prosecution of the war to warrant a different decision. ${ }^{39}$ William Ridgeway, eccentric and belligerent Disney 
Professor of Archaeology, who had proposed that the leave was not granted, withdrew his own application for leave of absence immediately after this decision had been taken. ${ }^{40}$ Two weeks later he complained 'that information as to his having opposed an application for leave of absence by a Professor had been communicated to the Professor concerned, and it was agreed that Dr Ridgeway's protest against such action should be recorded in the Minutes'. ${ }^{4}$

The rejection of Quiller-Couch's application had apparently raised uproar among the still relatively small number of university staff (1920: 57 professors, 23 readers and 64 lecturers; see figure 2A). Sir Arthur Quiller-Couch protested himself over a period of several years by handing in 'residence returns', which accounted for his absences during term time, only after a special reminder by the Secretary of the General Board. This in turn led Sir William Ridgeway to give notice in June 1921 that 'he would move at the next meeting of the Board that the Secretary of the Financial Board be instructed not to pay Sir Arthur QuillerCouch the next quarter's salary until he sent in his return'. ${ }^{42}$ The motion did not become necessary, but the incident shows how the granting of leave of absence relied on the good-will of one's colleagues and that a negative decision by the General Board, even in the exceptional period of war, had the potential not only to disturb personal relations but the smooth operation of university life for some time. ${ }^{43}$

Over the whole period under study, the General Board conducted a very generous policy towards granting leaves of absence. Only $0.9 \%$ of all recorded applications for leave of absence were not granted. In $4.6 \%$ of all cases, the decision was postponed to get more information from the applicant, to confirm the support of the relevant Faculty Board, or because the applicant had just made a preliminary inquiry to assess the chances of approval. Most applications stated that they had already got the consent of the Head of Department or the Faculty Board so that the decision of the General Board could mostly be regarded as a 
formal approval of arrangements previously agreed within the relevant departments and faculties. $^{44}$

While the annual number of applications remained rather low after the war, presumably influenced by the controversy about Sir Quiller-Couch's leave of absence, the jump in applications in the late 1920s relates to new regulations implemented in the University Statutes of 1926. Most importantly, the new Statutes provided rules for the 'periodic' or 'sabbatical' leave as it had become known from American universities. ${ }^{45}$ Every University Teaching Officer was now entitled to take off one term for every six terms of service, which corresponds to one year, or three terms, after six years of service; the salary being agreed by the General Board. ${ }^{46}$ It remained possible to obtain 'occasional' or 'additional' leave of absence on account of illness or any other sufficient cause such as lecturing in another university or undertaking work on behalf of the government. ${ }^{47}$ The new rules applied not only to Professors and Readers as before, but included Lecturers, Demonstrators, Assistant Lecturers and a few other academic posts whose holders previously had not been obliged to apply for leave of absence (even if some did so). ${ }^{48}$ In the following decades under consideration, these regulations were frequently amended and adjusted, particularly in regard to financial arrangements, but they did not change in principle.

The introduction of sabbatical leave was part of the third major university reform that helped to transform Cambridge into a modern research university. Following the Royal Commissions on Oxford and Cambridge of 1852 and 1874, a third Commission, set up in 1919 and chaired by former Prime Minister Herbert Henry Asquith (1852-1928), initiated new constitutions and revised the statutes of both universities and their colleges. Building on the Universities of Oxford and Cambridge Act 1923, as well as on the Universities and College Estates Act 1925, the whole process of reform was completed by 1926. The Asquith Commission's recommendations of 1922 concerned four major areas: university government, 
the organisation of teaching and research work, the accessibility of the universities and colleges to poor students and the place of women in the universities. ${ }^{49}$ According to Christopher Brooke, one of the Commissioners' first concerns was 'to ensure that university teachers had sufficient time for research and the instruction of ... postgraduate students', ${ }^{50}$ However, he elaborates that:

In spite of their strong emphasis on research, the Commission of 1922 proceeded rather hesitantly in their support of study leave. They refused to propose the institutions 'of a "Sabbatical Year" 'for reasons of public economy', but urged that a fund be set up to help meritorious cases for leave. ${ }^{51}$

The fact that the University of Cambridge Statutory Commissioners, who completed what the Royal Commissioners had begun, incorporated both a leave of absence fund and sabbatical leave in the new University Statutes of 1926 illustrates the association between research, study leave and travel.

In other studies of cross-boundary science, the period before World War One has been associated with the emergence of international academic travel and collaboration. This development was influenced by the 'transport revolution' related to steamship and railway travel and linked to the rise of international standards in methods, units, taxonomies and equipment. $^{52}$ Evidence from Cambridge, however, suggests that only lecturing abroad, primarily in the United States, played a major role in the period 1910/11 to 1913/14 and then again in $1920 / 21$ to $1924 / 25$, while the introduction of the new regulations in 1926 prompted a qualitative difference in the annual number of applications for academic leave, especially for research-oriented sabbatical leave. Based on different types of leave of absence, the new regulatory framework provided regular opportunities to focus on research and travelling for an extended period of time and thus to plan periods of research in advance. The new rules thereby contributed to the professionalisation of research in the ancient university. 
The increase of academic travel triggered by the university reform of 1926 and by a growing number of university teachers was interrupted by the impact of the world economic crisis between 1931 and 1933 and ended abruptly at the beginning of World War Two. In comparison to the academic year 1937/38, the number of applications for leave of absence more than doubled in the academic year 1939/40. The university released teaching officers at all career stages and in all academic fields in order to engage in military, academic and administrative work related to the war at home and abroad. In May 1940, the number of staff had already been decreased so much that the General Board adopted a more restrictive policy in releasing their academic staff for both volunteering service and service on demand. ${ }^{53}$

In the war years of 1939 to 1945, travel for academic reasons was significantly reduced and often had a specific political agenda. In 1940, for example, Baron Edgar Douglas Adrian, Professor of Physiology and Nobel Prize Winner of 1932, had been asked by the British Council to give some lectures in South America 'for propaganda purposes'. ${ }^{54}$ While he did not go at the time, Joseph Needham, Reader in Biochemistry at Cambridge, got invited by the British Council in 1942 to visit China 'on a mission to increase the mutual understanding between Britain and China in the field of science and learning, ${ }^{55}$ Based on his earlier preoccupation with Chinese language and history, Needham's journey was so successful that he stayed as the director of the Sino-British Scientific Co-operation Office in Chongqing until 1946. Subsequently, he published the celebrated Science and Civilisation in China (17 volumes of which appeared from 1954 until Needham's death in 1995), an achievement that 'effectively changed the way the world understood the development of science' and earned Needham the well-deserved reputation as a renowned sinologist and historian of science. ${ }^{56}$

When John Cockcroft, Jacksonian Professor of Natural Philosophy, went to Canada in order to take charge of the Canadian Atomic Energy project as the director of the Montreal and Chalk River Laboratories from 1944 to 1946, he kept in close contact with Cambridge. 
Two demonstrators in physics, Hugh Carmichael and Charles Walton Gilbert, were released from the university to work in Cockcroft's group in Canada. ${ }^{57}$ In spring 1946 , Cockcroft also invited Ronald George Norrish, Professor of Physical Chemistry, with a view of studying physico-chemical problems connected with the utilisation of atomic energy. Norrish took advantage of being in North America and also travelled to other 'physical chemical laboratories in Canada and the United States in order to study their construction and equipment' 58

In the first post-war decade, when the age of travel by ship was slowly being replaced by the age of commercial air transport, academic travel experienced an unprecedented growth. In Cambridge, this growth was related to an expanding body of university teachers, particularly at the lecturer level, a growing number of applications for academic leave of absence and a more standardised process of application. Academic leave of absence comprised $56.6 \%$ of all 1,826 granted applications from $1885 / 86$ to $1954 / 44$. The vast majority of these 1,034 academic leaves were granted in the last three decades under consideration; the post-war decade alone accounting for over half. Accordingly, the relation of granted academic leave per professor and reader rose from 0.2 in the decade 1885-94 to 2.1 in the decade 1945-54 (figure 2). In the post-war decade, on average, 23.8\% of Cambridge professors were granted academic leave in any one academic year, while an average of $5.7 \%$ of them was on sabbatical in each academic year. ${ }^{59}$

[Figure 2 about here]

The historical development of leave of absence at Cambridge University proceeded from the modest beginnings of institutionalised academic travel before 1914 to its boom in the post-war decade (figure 1). The following analysis details how the geographies of academic travel varied over time and among different types of work. It also examines to what extent the 
motivations for and destinations of academic travel were influenced by scientific, political, economic and other interests.

\section{THE GEOGRAPHY OF INTERNATIONALISATION}

Academic leaves of absence by Cambridge University Teaching Officers were roughly equally divided between short-term absences of up to one month (33\%), medium-term absences of over one to three months (35\%) and long-term absences of more than three months $(28 \%) .{ }^{60}$ While long absences increased after World War One, short-term absences slightly increased in the post-war period, which can be explained by improved transportation and a growing emphasis on short-term lecturing and conference travel. Out of the 1,034 granted academic leaves, $38.8 \%$ were sabbatical leaves, $46.0 \%$ additional leaves and $15.2 \%$ other types of leaves. In the post-war decade, this relation amounted to $40.2 \%$ sabbatical leaves, $56.8 \%$ additional academic leaves and $3.0 \%$ other academic leaves. ${ }^{61}$ At least $81.4 \%$ of all granted academic leaves had a destination outside Cambridge, while at least $72.7 \%$ involved travelling abroad, which illustrates that the history of academic leave of absence is largely a history of academic travel (table 1). ${ }^{62}$

\section{$\underline{\text { Anglo-American Ties }}$}

In the late nineteenth and early twentieth centuries, Cambridge academics travelled to a few places scattered around the globe. Archaeologists and scholars of oriental languages conducted research in Italy, Greece, Cyprus, Syria and Egypt. Conference visits were paid to Germany, Austria and Italy - all before World War One - and also to Australia, Japan, Canada and the United States. From 1895 onwards, a number of Cambridge academics were invited to give lectures at Harvard, Princeton, Yale, Johns Hopkins and several other American universities. In 1902, Peter Giles, Professor of Philology, visited Columbia 
University in New York to assist with the foundation of a new Professorship of Chinese. ${ }^{63}$ In the academic year 1916/17, Terrot Glover, Lecturer in Ancient History, was the first Cambridge academic who is recorded to have served as a deputy professor in America. ${ }^{64}$ This mobilisation of expertise, mainly in the form of invited lectures and visiting appointments, intensified in the following decades and can be regarded as an important contribution to the emergence of American universities as worldwide academic centres.

A key context for this development was the success of the German research university in the second half of the nineteenth century, of which 'the rest of Europe and North America had to take note and then action. ${ }^{95}$ With the foundation of Johns Hopkins University in 1876, modern research and graduate training in the style of the German university had begun to take shape in the United States, while the 1890s, as William Clark noted, 'constituted the takeoff decade for the diffusion of the graduate school in America' ${ }^{66}$ It seems to be no accident that seven of the 14 recorded academic travellers from Cambridge in the decade 1895/96 to 1904/05 went to the United States. On the one hand, the period 1898 to 1906 has been described as the 'formative years of Anglo-American understanding'. ${ }^{67}$ On the other hand, 'many sensed that American graduate programs had attained near or actual parity' by that time. ${ }^{68}$ The related research expertise and newly established laboratories and libraries constituted a major attraction for Cambridge academics, resulting in growing AngloAmerican academic ties that flourished on the basis of a common English language.

Bearing these global geographies of higher education and research in mind, the institutionalisation of academic travel at Cambridge University in the 1880s appears to be both the result of a pressure for modernisation and professionalisation, coming, inter alia, from the 'improved' German university model at the newly established US research universities, and a contribution to the development of an Anglo-American academic hegemony in the twentieth century. ${ }^{69}$ It also means that the idea of the modern research 
university as first embodied by the German university model was imported to Cambridge via the United States. The existence of relatively few links between the competing knowledge centres of Germany and England is underlined by the small number of Cambridge academics travelling to the world-wide centres of academic knowledge in Germany before 1945 and particularly in the decade after World War One (table 1). ${ }^{70}$

[Figure 3 about here]

In the period 1925-44, academic travel from Cambridge University was not only increasingly directed to the United States: it also intensified within Europe and extended to British colonies in the west Atlantic, in Africa, and in south and south-east Asia (figure 3). In the first two decades of the twentieth century, especially, Cambridge academics often followed the routes of imperial power, much as their French counterparts supported by the Service de Mission did, thus underlining the close relationship between scholarship and the European imperial project in this period. $^{71}$ The post-1945 decade, however, saw the emergence of an increasingly postcolonial transnational exchange (table 1). Despite the global reach of travel destinations, the increasing internationalisation from pre-war to post-war decade was characterised by a disproportionate rise in academic travel to the United States, which demonstrated the existence of a closely linked Anglo-American world by the midtwentieth century. As a result of decolonisation and European integration, in the post-1945 decade academic travel to continental Europe became much more important than to the British Empire. ${ }^{72}$

The following analysis of travel for different types of academic work reveals in more detail the ways in which asymmetrical power-relations between different places were articulated in the global flows of Cambridge academics.

[Table 1 about here] 


\section{$\underline{\text { Asymmetrical Power Relations }}$}

Cambridge academics often travelled for a mix of reasons, combining lecture tours with conference visits, research with consulting or academic tasks with private affairs. Sir Ernest Rutherford, Director of the Cavendish Laboratory and Nobel Prize Winner in Chemistry in 1908, was granted leave of absence in the Michaelmas Term 1925 in order to visit his parents in New Zealand and to give lectures in the major towns of Australia and New Zealand. ${ }^{73}$ George Nuttall, Professor of Biology, went to California in the Easter Term 1924 in order to deal with legal matters in connection with his late sister's estate, to deliver some lectures, to receive an honorary degree from the University of California at San Francisco, where he had graduated 40 years before, and to visit various scientific institutions in North America before attending the Meeting of the British Association in Toronto. ${ }^{74}$ Despite the complex nature of motivations for academic travel, it is possible to identify five main types of work that show distinct geographical patterns of destinations at the global scale: research and travelling (35.4\%), visiting appointments (9.9\%), lecturing (17.9\%), conference visits and representation $(18.2 \%)$, and administration and consulting $(10.4 \%){ }^{75}$

Travelling for the purpose of research and learning aimed at a variety of places across the globe (figure 4A). By mobilising heterogeneous resources such as samples, artefacts, collaborators, knowledge and ideas in different parts of the world in order to construct new knowledge claims, Cambridge academics contributed to making their university a Latourian 'centre of calculation'. According to Bruno Latour, the recurring mobilisation of 'anything that can be made to move and shipped back home' in scientific centres of calculation - such as the university, the laboratory, the archive and the museum - shaped the cumulative character of European science from the ages of discovery and exploration and established Europe as the centre of the imperial age. Essentially, each full 'cycle of capitalisation' created an advantage in knowledge that made distant places familiar and thus controllable. ${ }^{76}$ 
From this perspective, the University of Cambridge can be conceptualised as a site of knowledge production and dissemination that was constituted and maintained to a considerable extent by the travels of its academics. ${ }^{77}$ Representing a central institutional node within the global networks of academia, Cambridge University was embedded within a complex set of overlapping processes of mobilisation by different centres of calculation. Exemplified by increasing travels of Cambridge academics to the United States, these travels not only served the travellers' experiences and resources, but also helped to mobilise external prestige and expertise in the new American research universities. Accordingly, more than two thirds of all visiting appointments of Cambridge academics between 1885/86 and 1954/55 were based at American universities (table 2). American universities were able to offer these temporary posts of three to twelve months because they possessed the necessary financial resources to mobilise foreign prestige and expertise, while the prospect of learning about the latest research infrastructure was attractive even for established Cambridge academics. At the time, these circumstances were only to be found in a few other places world-wide; most of which were located within the British Empire, while there were only five visiting appointments held in the competing centres of knowledge production across continental Europe - none of them in the natural and technical sciences (figure 4C). ${ }^{78}$

[Figure 4 about here]

The global geographies of lecturing showed similar regional clusters to those for conference travel (figure 4B). Characterised by short-term absences, more than half of the conference travel by Cambridge academics focused on established European research centres. In comparison, the United States was less important, while destinations in the British Empire and other places, including India, Australia and Russia, were of more significance for this type of transnational academic exchange. In 1914, three Cambridge professors and one reader joined over three hundred British scientists to take part in the 84th meeting of the British 
Association for the Advancement of Science in Australia. Further large international meetings attended by Cambridge academics included the Pacific Science Congresses in Australia (1923), Japan (1926) and Canada (1933), the India Science Congresses (1938, 1947, 1953, 1955) - both events had been modelled after the meetings of the British Association - and the first General Conferences of the UNESCO in Mexico City (1947) and Beirut (1948). ${ }^{79}$ Closely linked academic and political interests were particularly evident in the case of several lecture tours and conference visits to the Middle East in the post-war period, often arranged through the British Council. In July 1946, the permanent undersecretary of the Foreign Office, Orme Sargent, identified the Middle East as a region of prime importance for the future of the British Commonwealth, and this resulted in a concerted policy that aimed at boosting Britain's image in the region, in competition with not only the Soviet Union but also the United States and France. ${ }^{80}$

[Table 2 about here]

Cambridge academics were also involved in a number of consulting and administrative jobs for the British government, for colonial governments, and for international organisations and corporations (figure 4D). In the post-war decade, for example, Cambridge academics advised on Jewish Education in Palestine (1946), nutritional problems in the British Zone of Germany (1946) and land drainage in Poland (1947). They gave advice on the sugar industry in British Guiana (1949), assisted the New Zealand Government in bringing into operation the new constitution of Western Samoa (1949) and commented on proposals for a higher college for Africans in the British Central African Territories (1952). In 1954, Cambridge academics helped the Anglo-Iranian Oil Company with legal problems arising from the re-opening of the Iranian oil fields, served as Economic Advisors to the Iraq Development Board and investigated an outbreak of disease in poultry in Egypt. In 1955, they inquired into a threatened labour dispute in the oil industry of Trinidad, made recommendations for land 
reform in Ceylon and advised the Government of Sierra Leone about the reconstruction of their cost of living index.

A notable example of this consultancy role is provided by the career of Sir Frank Leonard Engledow (1890-1985), Lecturer in Agriculture and Forestry from 1926 to 1930 and Drapers' Professor of Agriculture from 1930. Between November 1927 and June 1954 he made 14 applications for leave of absence to the General Board - more than anyone else for academic reasons and almost all for consulting purposes. His strong ties with governmental and colonial organisations are expressed in consulting jobs he accepted for the Empire Cotton Growing Corporation (to inspect Government experimental stations in Nigeria, 1928), the Empire Marketing Board (to inspect the Cotton Research Institute and the Imperial College of Tropical Agriculture at Trinidad, 1929) and the Secretary of State for the Colonies (to inquire into the affairs of the Rubber Research Institute of Malaya, 1933). He also did research on tea for the Indian Tea Association (1935/36), advised the government of Sudan and acted as a member of a Royal Commission to report on the economic and social conditions in the West Indies (both in the academic year 1938/39). Engledow seemed to exemplify what Roy MacLeod called the period of cooperation in the history of British imperial science. ${ }^{81}$

After World War Two, Engledow applied almost every academic year for leave of absence of up to five months, which provoked suspicion among members of the General Board. They did not approve his application to attend the Indian Science Congress in November 1946 and asked for a list of his academic leaves before allowing him 'to visit Southern Rhodesia, at the invitation of the Government of that Colony, to advise them on matters connected with the country's agricultural development' in October $1947 .{ }^{82}$ However, despite Engledow's long list of absences, the General Board continued to approve his travels during term time, probably being aware of the potential benefits for the university. When he planned visiting Uganda on the invitation of the Colonial Office and the Empire Cotton 
Growing Corporation in 1952/53, the General Board gave its consent 'on the understanding that the inviting bodies would be responsible for re-imbursing the University for the cost of the stipend accruing to the Professor during his absence'. Four months later, however, the General Board reconsidered this decision and accepted Engledow's wish of 'not asking for reimbursement' as 'the Empire Cotton Growing Corporation, on whose invitation he was visiting Uganda, had for some years past made generous contributions to the funds of the Department of Agriculture'. ${ }^{83}$

While the expertise created by research and teaching at Cambridge had strongly benefited from colonial ties, these examples illustrate how it was in turn deployed in the running of the British state and empire, the reconstruction of post-war Europe and the creation of favourable postcolonial relations within the British Commonwealth. Academic and political interests often went hand in hand when Cambridge academics travelled abroad. Their journeys refer to an important chapter in Europe's appropriation of non-European regions that contributed to strong colonial and later postcolonial ties. ${ }^{84}$ The fact that Joseph Needham was a prominent supporter of UNESCO and that in the period under consideration other Cambridge academics worked for the United Nations and the predecessor organisations of OECD and European Union indicates the continuing significance of supranational organisations - and by extension academic travel - for the development of the modern university. $^{85}$

\section{Global Patterns}

Comparing the global geographies of academic travel from Cambridge University for different types of work reveals distinct patterns of interaction. The sites where academics held visiting appointments, gave lectures and attended conferences tended to represent regional clusters of knowledge production centres (figure 4B and 4C), while research travel and 
consulting involved many more places across the globe (figure 4A and 4D). As the places where resources were mobilized through research practice were often different to those where scientific results were presented and debated, the mapping of academic travel from Cambridge University reveals some of the ways in which different academic practices required different spatial contexts that themselves showed distinct global geographies. These geographies were to some extent produced by the geographically uneven distribution of what Pierre Bourdieu categorized as cultural, symbolic, social and economic capital. ${ }^{86}$ Visiting appointments, lectures and conferences, for example, clustered in those places able to offer like-minded experts with the interest, prestige, financial resources, infrastructure and networks to attract other academics and to successfully host these events. In the period under study, the discussion of research findings appeared to be a very Eurocentric endeavor with a growing importance of US research universities as the embodiment of modern science and higher education. The process of knowledge production, however, relied heavily on resources from all over the world. A comparison of travel destinations for research and consulting exposes the great significance of political interests for academic consulting as most destinations were to be found within the British Empire overseas, followed by the United Kingdom itself (table 2).

These asymmetric global geographies of academic travel were also shaped by what Derek Gregory has called 'a double geography' of 'a hierarchy of spaces of knowledge production in which some sites are valorized as more central than others' and 'a hierarchy of sites of study in which some places are valorized as canonical or exotic, as exemplary sites of consuming interest, whereas others are marginalized as merely other, less interesting or less instructive instances of more general conditions that are better exemplified elsewhere'. ${ }^{87}$ While the concentration of visiting appointments in the United States refers to the new apex of sites of knowledge production, a much more complex picture emerges in the case of 
research travel. For example, research practices involving the exploration of physical territories and the collection of samples often did not require any special on-site infrastructure (other than the equipment the researchers brought along). Accordingly, travel destinations for field work in the physical and biological sciences were scattered in various, and often remote, places across the globe. Highly specialised laboratory equipment and expertise, however, required ongoing investments of economic and cultural capital in situ. This was only available in the richer regions of the world, leading to global patterns of interaction with regional clusters of travel destinations in the United States and continental Europe. In the social sciences, research travel mainly concentrated on the United States, a destination that combined renowned spaces of knowledge production with attractive research infrastructure, while research travel in the humanities was characterized by a few regional clusters and a few scattered travel destinations, representing the interests of highly specialized scholars. Remarkably, the southern hemisphere attracted only five Cambridge research travellers from across the whole spectrum of the social sciences and the humanities in the period under consideration (3.4\%), suggesting a distinct North-South difference in the production of humanistic knowledge at the time.

\section{CONCLUSION}

Academic travel from Cambridge University in the period $1885 / 86$ to $1954 / 55$ contributed significantly to the formation of modern research universities as global centres of knowledge production and dissemination. Cambridge itself benefited from the mobilisation processes of its academics in various ways, including the production of new knowledge claims, the access to and import of new ideas, prestige, objects and infrastructure, the linking to academic networks and prospering research centres and the raising of funds for the university. Other institutions, such as the new research universities in the United States, began to mobilise 
visiting Cambridge academics from the 1890s onwards and emerged as prominent centres of science and learning in the first half of the twentieth century. The institutionalisation of academic travel at Cambridge during a major university reform in the 1880 s can be seen as both the result of a need for modernisation in face of the newly established US research universities and a contribution to the development of an Anglo-American academic hegemony in the twentieth century.

A part of the modern research culture in the United States since the 1880s, the idea of the 'sabbatical' leave arrived in Cambridge only in 1926, during another major university reform that explicitly promoted research work. The related professionalisation and internationalisation of academic travel was shaped by intensifying Anglo-American relations and changing power-geometries of world politics. Destinations in the British Empire figured prominently in the first three decades of the twentieth century but their importance decreased with decolonisation, while European reconstruction after 1945 was accompanied by growing academic ties with the continent. The strong interrelation of academic expertise and political interests was also underlined by academic travel to regions of strategic importance to Britain such as Africa and the Middle East and by consulting work for colonial institutions and postcolonial supranational organisations.

Comparing the geographies of academic travel for different types of work has revealed distinct geographical patterns of interaction on the global scale. Based on the empirical analysis presented here, I argue that the global flows of Cambridge academics were shaped in at least four ways: first, they were inextricably linked to international politics; second, they were produced by a complex set of overlapping mobilisation processes by different centres of calculation; third, they were moulded by the geographically uneven distribution of cultural, symbolic, social and economic capital; and, fourth, they were influenced by varying spatial relations of the practices conducted at the travel destinations. In order to better understand the 
geographies of knowledge, science and higher education, it is particularly important to examine further the relationship between academic travel and the social and material specificities of different scientific practices.

In conclusion, this study has shown that the rise of a research culture at modern universities went hand in hand with an emphasis on academic travel. Academic travel can thus be regarded as a constitutive element in the formation of modern research universities as centres of knowledge production. Following David Lux and Harold Cook, this also means that 'viewing science in action situated in one location ..., without taking account of the many people coming and going to and from other sites, overlooks something essential'. ${ }^{88}$ As illustrated by the existence of an Anglo-American academic hegemony since the midtwentieth century, these essential global geographies of academic travel, particularly with regard to socially important practices such as visiting appointments, lecturing and conference travel, do also indicate the rise and intensification of academic networks and thus help to anticipate future changes in the geographies of knowledge, science and higher education. ${ }^{89}$

\section{Acknowledgements}

I wish to thank the Alexander von Humboldt Foundation, the University of Nottingham and the Cambridge University Archives for supporting this work. I am particularly grateful to Mike Heffernan for hosting my stay as a Feodor Lynen Postdoctoral Research Fellow at the School of Geography, University of Nottingham, and for providing invaluable input and encouragement at all stages of this project. Felix Driver as the editor, Alexa Färber, Tim Freytag, Michael Hoyler, Phil Hubbard and three anonymous referees also kindly provided thoughtful comments on earlier versions of this paper. 


\section{TABLES}

Table 1

Destinations of academic leaves at Cambridge University by decade (in \% of academic leaves)

\begin{tabular}{|c|c|c|c|c|c|c|c|c|}
\hline from & $1885 / 86$ & $1895 / 96$ & 1905/06 & 1915/16 & $1925 / 26$ & $1935 / 36$ & $1945 / 46$ & $1885 / 86$ \\
\hline Destination & $1894 / 95$ & 1904/05 & 1914/15 & $1924 / 25$ & $1934 / 35$ & $1944 / 45$ & $1954 / 55$ & $1954 / 55$ \\
\hline 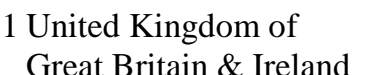 & 417 & 71 & 207 & 69 & 114 & 7.3 & 118 & 114 \\
\hline thereof Cambridge & 0.0 & 12.5 & 0.0 & 0.0 & 4.0 & 2.9 & 2.1 & 2.7 \\
\hline 2 Abroad & 50.0 & 85.7 & 75.9 & 89.7 & 63.2 & 64.2 & 77.4 & 72.7 \\
\hline $\begin{array}{l}\text { a British Empire } \\
\text { overseas (as of 1914) }\end{array}$ & 16.7 & 21.4 & 20.7 & 24.1 & 17.6 & 17.6 & 14.5 & 16.2 \\
\hline $\begin{array}{l}\text { b United States of } \\
\text { America }\end{array}$ & 16.7 & 50.0 & 31.0 & 48.3 & 17.6 & 22.4 & 31.4 & 27.9 \\
\hline c Continental Europe & 8.3 & 21.4 & 20.7 & 10.3 & 21.2 & 17.6 & 26.5 & 23.2 \\
\hline thereof Germany & 0.0 & 7.1 & 3.4 & 0.0 & 5.2 & 1.8 & 4.7 & 4.2 \\
\hline $\mathrm{d}$ Other places & 8.3 & 0.0 & 3.4 & 10.3 & 8.8 & 6.7 & 7.6 & 7.5 \\
\hline 3 Not specified & 8.3 & 7.1 & 3.4 & 3.4 & 25.4 & 28.5 & 10.8 & 15.9 \\
\hline $\begin{array}{l}\text { Number of } \\
\text { Academic leaves }\end{array}$ & 12 & 14 & 29 & 29 & 193 & 165 & 592 & 1,034 \\
\hline
\end{tabular}

Sources: Cambridge University Archives, Minutes of the General Board, GB Min III.1 to GB Min III.7 and GB 160, Boxes 301 to 307. 
Table 2

Destinations of academic leaves at Cambridge University by type of work (in \% of academic leaves)

\begin{tabular}{|c|c|c|c|c|c|c|c|}
\hline $\begin{array}{r}\text { Type of } \\
\text { work }\end{array}$ & $\begin{array}{r}\text { Research } \\
\& \text { travel- } \\
\text { ling }\end{array}$ & $\begin{array}{r}\text { Visiting } \\
\text { appoint- } \\
\text { ment }\end{array}$ & Lecturing & $\begin{array}{l}\text { Con- } \\
\text { ference } \\
\& \text { repre- } \\
\text { sentation }\end{array}$ & $\begin{array}{r}\text { Admini- } \\
\text { stration } \\
\& \text { con- } \\
\text { sulting }\end{array}$ & $\begin{array}{r}\text { Unspeci- } \\
\text { fied } \\
\text { sabbatical } \\
\text { leave }\end{array}$ & $\begin{array}{r}\text { Total } \\
1885 / 86 \\
\text { to } 1954 / 55\end{array}$ \\
\hline $\begin{array}{l}1 \text { United Kingdom of } \\
\text { Great Britain \& Ireland }\end{array}$ & 14.5 & 1.0 & 16.0 & 3.8 & 23.1 & 2.4 & 11.4 \\
\hline thereof Cambridge & 6.0 & 0.0 & 0.0 & 0.0 & 3.7 & 2.4 & 2.7 \\
\hline 2 Abroad & 66.1 & 99.0 & 83.5 & 95.1 & 70.4 & 0.0 & 72.7 \\
\hline $\begin{array}{l}\text { a British Empire } \\
\text { overseas (as of 1914) }\end{array}$ & 15.6 & 19.6 & 10.6 & 15.7 & 38.0 & 0.0 & 16.2 \\
\hline $\begin{array}{l}\text { b United States of } \\
\text { America }\end{array}$ & 26.2 & 71.6 & 38.3 & 20.0 & 10.2 & 0.0 & 27.9 \\
\hline c Continental Europe & 15.6 & 4.9 & 33.5 & 52.4 & 16.7 & 0.0 & 23.2 \\
\hline thereof Germany & 3.6 & 1.0 & 7.4 & 7.0 & 1.9 & 0.0 & 4.2 \\
\hline d Other places & 12.0 & 4.9 & 3.2 & 8.1 & 7.4 & 0.0 & 7.5 \\
\hline 3 Not specified & 19.4 & 0.0 & 0.5 & 1.1 & 6.5 & 97.6 & 15.9 \\
\hline $\begin{array}{l}\text { Number of } \\
\text { Academic leaves }\end{array}$ & 366 & 102 & 188 & 185 & 108 & 85 & 1,034 \\
\hline
\end{tabular}

Sources: Cambridge University Archives, Minutes of the General Board, GB Min III.1 to GB Min III.7 and GB 160, Boxes 301 to 307. 


\section{FIGURES}

Figure 1

Applications for leave of absence by Cambridge University Teaching Officers, 1885/86 to 1954/55

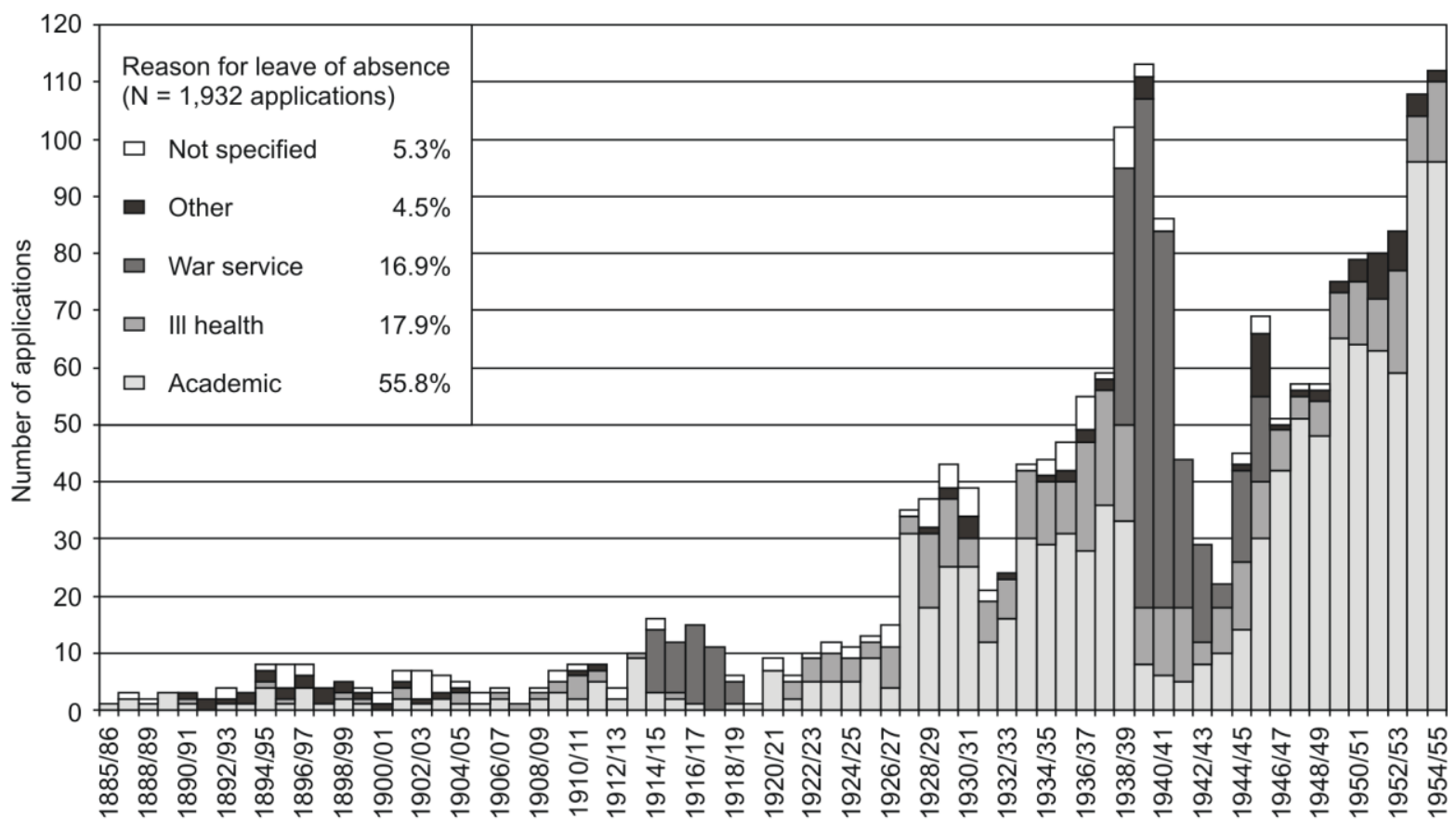

Sources: Cambridge University Archives, Minutes of the General Board, GB Min III.1 to GB Min III.7 and GB 160, Boxes 301 to 307. 
Figure 2

Cambridge University Teaching Officers and granted academic leaves by decade
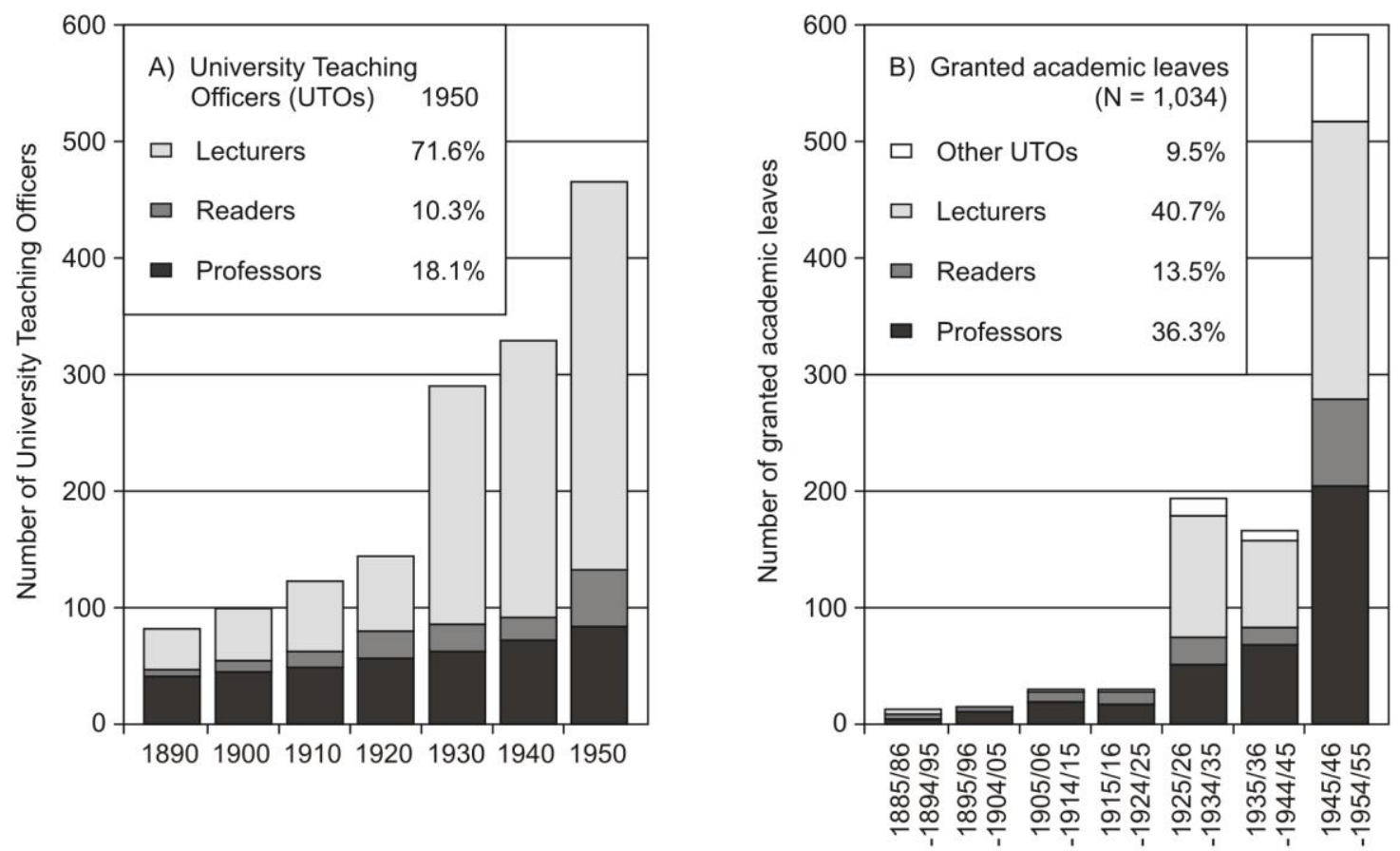

Sources: A) Cambridge University Calendar, 1890, 1899/1900; Cambridge University Reporter, 1909/10, 1919/20, 1929/30, 1939/40, 1949/50; B) Cambridge University Archives, Minutes of the General Board, GB Min III.1 to GB Min III.7 and GB 160, Boxes 301 to 307. 
Figure 3

Destinations of academic leaves from Cambridge University, 1885/86 to 1954/55

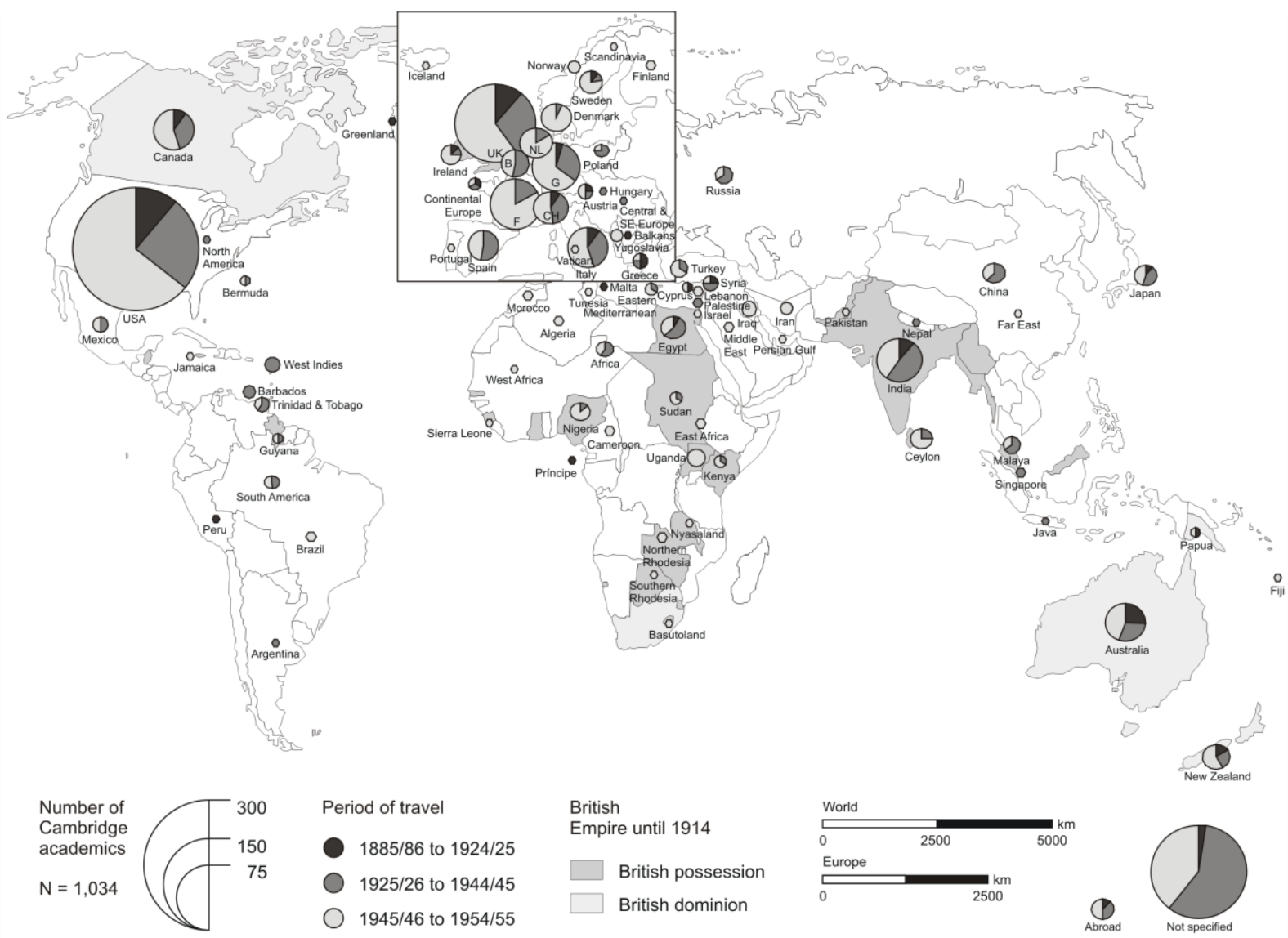

Sources: Cambridge University Archives, Minutes of the General Board, GB Min III.1 to GB Min III.7 and GB 160, Boxes 301 to 307. 
Figure 4

Destinations of academic leaves from Cambridge University by different types of work, 1885/86 to $1954 / 55$
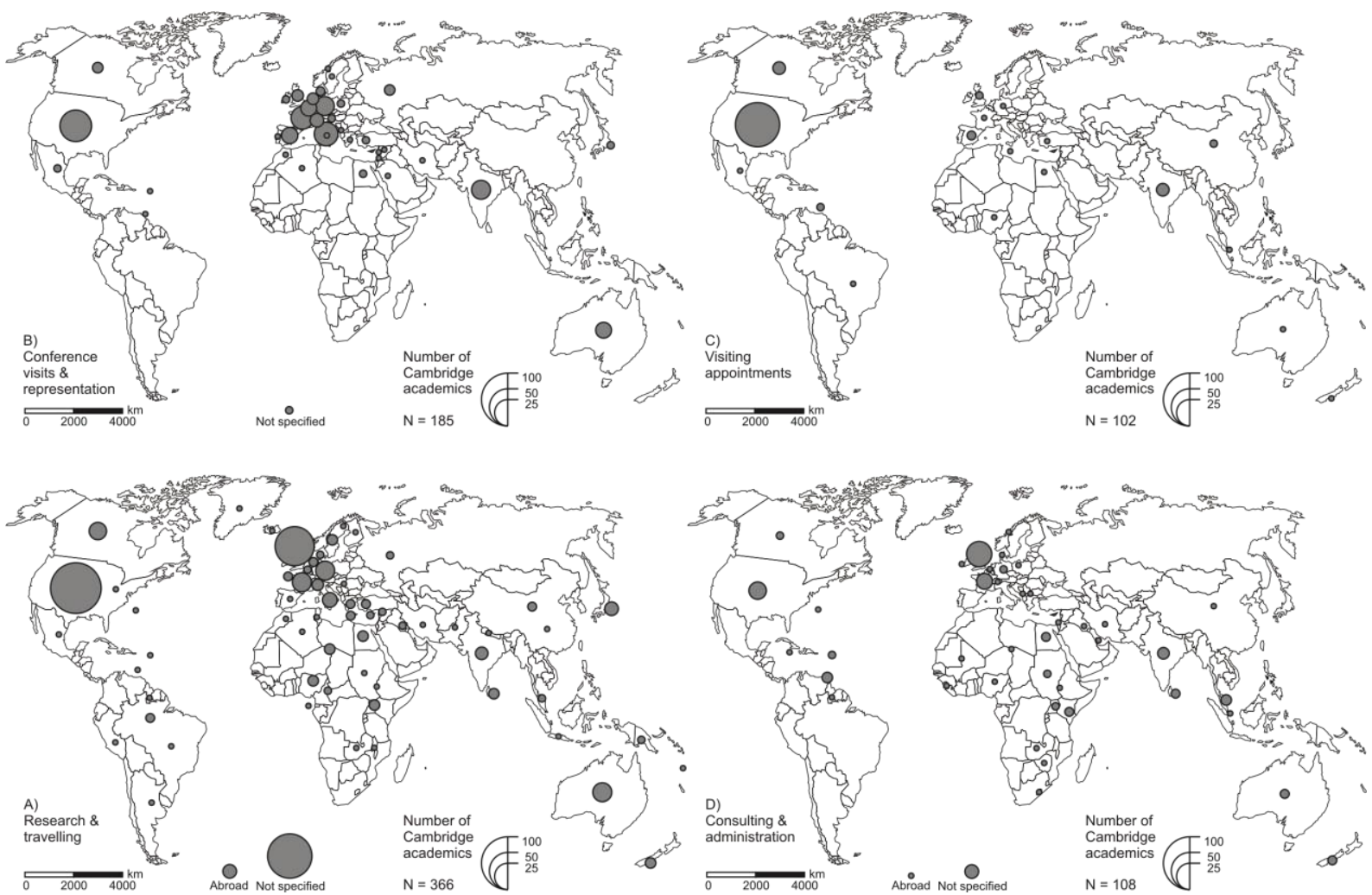

Sources: Cambridge University Archives, Minutes of the General Board, GB Min III.1 to GB Min III.7 and GB 160, Boxes 301 to 307. 
Figure 5

Research travel from Cambridge University in different fields, 1885/86 to $1954 / 55$
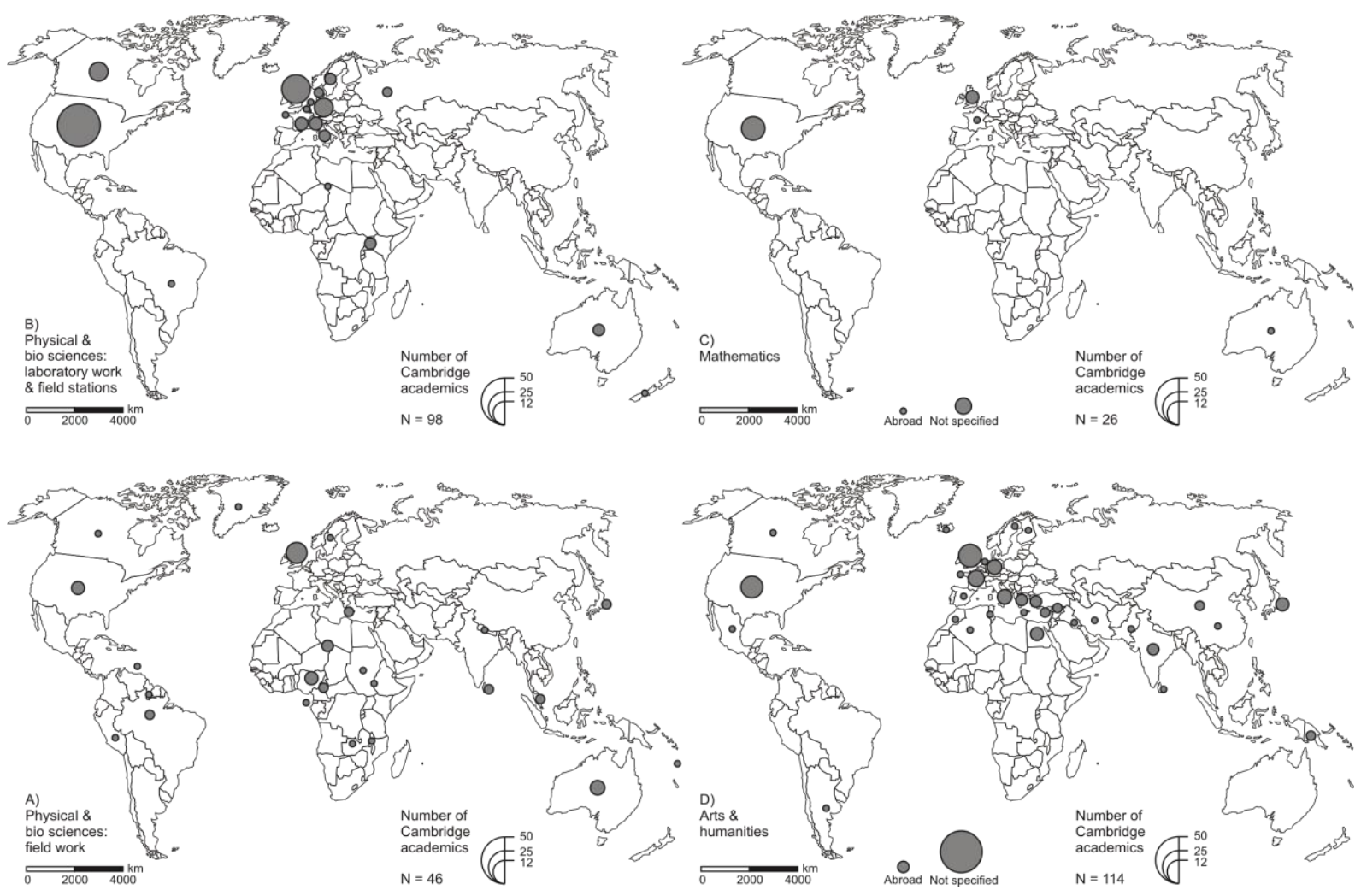

Sources: Cambridge University Archives, Minutes of the General Board, GB Min III.1 to GB Min III.7 and GB 160, Boxes 301 to 307. 


\section{NOTES}

${ }^{1}$ See, for example, P.G. Altbach, The new internationalism: foreign students and scholars, Studies in
Higher Education 14 (1989) 125-136; P. Blumenthal, C.D. Goodwin, A. Smith, U. Teichler (Eds),
Academic Mobility in a Changing World: Regional and Global Trends, London, 1996; OECD (Ed.),
Internationalisation of Higher Education, Paris, 1996; L. Ackers, Moving people and knowledge:
scientific mobility in European Union, International Migration 43 (2005) 99-131; R. Barnett, A. Phipps, Academic travel: modes and directions, The Review of Education, Pedagogy, and Cultural Studies 27 (2005) 3-16.

${ }^{2}$ B. Latour, Science in Action: How to Follow Scientists and Engineers Through Society, Milton Keynes, 1987, 210-211, 220-221.

${ }^{3}$ Latour, Science in Action, chapter 6.

${ }^{4}$ In a rich literature on modern exploration and scientific travel, important writings include D. Livingstone, The Geographical Tradition, Oxford, 1992, chapter 4; M.L. Pratt, Imperial Eyes: Travel Writing and Transculturation, London, 1992; S. Sörlin, National and international aspects of crossboundary science: scientific travel in the $18^{\text {th }}$ century, in E. Crawford, T. Shinn, S. Sörlin (Eds), Denationalizing Science: The Contexts of International Scientific Practice, Dordrecht, 1993, 43-72; A. Blunt, Travel, Gender and Imperialism, New York, 1994; M. Heffernan, A state scholarship: the political geography of French international science during the nineteenth century, Transactions, Institute of British-Geographers 19 (1994) 21-45; M.T. Bravo, Precision and curiosity in scientific travel: James Rennell and the orientalist geography of the new imperial age 1760-1830, in J. Elsner, J.P Rubiés (Eds): Voyages and Visions: Towards a Cultural History of Travel, London, 1998, 162183; D. Livingstone, C. Withers (Eds), Geography and Enlightenment, Chicago, 1999; F. Driver, Geography Militant: Cultures of Exploration and Empire, Oxford, 2001; A. Simoes, A. Carneiro, M.P. Diogo, Travels of Learning: A Geography of Science in Europe, Dordrecht, 2003. See also J. Duncan, D. Gregory (Eds), Writes of Passage: Reading Travel Writing, London, 1999; P. Hume, T. Youngs (Eds), The Cambridge Companion to Travel Writing, Cambridge, 2002. 
${ }^{5}$ For a recent history, see W. Clark, Academic Charisma and the Origins of the Research University, Chicago, 2006.

${ }^{6}$ D. Livingstone, Putting Science in Its Place: Geographies of Scientific Knowledge, Chicago, 2003, 177.

${ }^{7}$ R.C. Powell, Geographies of science: histories, localities, practices, futures, Progress in Human Geography 31 (2007) 309-329, 321. See also M.-N. Bourguet, C. Licoppe, H.O. Sibum (Eds), Instruments, Travel and Science: Itineraries of Precision from the Seventeenth to the Twentieth Century, London, 2002.

${ }^{8}$ For the history of science, see J.A. Secord, Knowledge in transit, Isis 95 (2004) 654-672.

${ }^{9}$ This interest is closely linked to recent work on historical and geographical variations in the production and dissemination of scientific knowledge. See A. Ophir, S. Shapin, The place of knowledge: a methodological survey, Science in Context 4 (1991) 3-21.; D.N. Livingstone, The spaces of knowledge: contributions towards a historical geography of science, Environment and Planning D: Society and Space 13 (1995) 5-34; S. Shapin, Here and everywhere: sociology of scientific knowledge, Annual Review of Sociology 21 (1995) 289-321; S.J. Harris, Long-distance corporations, big sciences, and the geography of knowledge, Configurations 6 (1998) 269-304; C. Smith, J. Agar (Eds), Making Space for Science: Territorial Themes in the Shaping of Knowledge, Basingstoke, 1998; D.N. Livingstone, Making space for science, Erdkunde 54 (2000) 285-296; D.N. Livingstone, Science, Space and Hermeneutics: Hettner-Lecture 2001, Heidelberg, 2002; D. Livingstone, Putting Science in Its Place; S. Naylor, Historical geographies of science: places, contexts, cartographies: special issue on the historical geographies of science, British Journal for the History of Science 38 (2005) 1-12.

${ }^{10}$ Barnett, Phipps, Academic travel, 5.

${ }^{11}$ K.J. Dean, Settler Physics in Australia and Cambridge, 1850-1950, University of Cambridge, PhD. Dissertation, Cambridge, 2005, 1.

${ }^{12}$ Heffernan, A state scholarship, 22; see also Driver, Geography Militant, 2-3.

${ }^{13}$ See, for example, Heffernan, A state scholarship; M. Patiniotis, Scientific travels of the Greek scholars in the eighteenth century, in A. Simoes, A. Carneiro, M.P. Diogo (Eds), Travels of Learning: 
A Geography of Science in Europe, Dordrecht, 2003, 47-75, 48-49, 51. Contemporary studies include U. Teichler (Ed.), ERASMUS in the SOCRATES Programme: Findings of an Evaluation Study, Bonn, 2002; H. Jöns, Geographies of international scientific exchange in their political context: the case of visiting scholars to Germany in the second half of the twentieth century, in J. Nemes Nagy, A. Jakobi (Eds), Frontiers of Geography, Budapest, 2003, 227-247.

${ }^{14}$ Heffernan, A state scholarship, 29.

${ }^{15}$ For the relationship between science and empire, see R. MacLeod, Passages in imperial science: from empire to commonwealth, Journal of World History 4 (1993) 117-150; Blunt, Travel, Gender and Imperialism; A. Godlewska, N. Smith (Eds), Geography and Empire, Oxford, 1994; M. Bell, R. Butlin, M. Heffernan (Eds), Geography and Imperialism, 1820-1940, Manchester, 1995; R. Drayton, Nature's Government: Science, Imperial Britain, and the 'Improvement' of the World, New Haven, 2000; Driver, Geography Militant; R.M. MacLeod (Ed.), Nature and Empire: Science and the Colonial Enterprise, Chicago, 2001; M. Harrison, Science and the British Empire, Isis 96 (2005) 5663.

${ }^{16}$ The standard history of the University of Cambridge in the twentieth century contains a chapter entitled 'The university and the world, 1945-1990: a cosmopolitan society'. Sketching some transnational influences without referring to travels by Cambridge academics, the text does mention 'the extensive travels of many British students [that] help to explain the rapid waves of fashion from distant places which have flowed into Britain'. See Christopher N. L. Brooke, A History of the University of Cambridge: Vol. IV - 1870-1990, Cambridge, 1992, 511-566, 520.

${ }^{17}$ Brooke, A History of the University of Cambridge, $\mathrm{xv}$.

${ }^{18}$ Brooke, A History of the University of Cambridge, xix.

${ }^{19}$ Data was supplemented from various sources, including personnel files available in the Cambridge University Archives, the 'List of Cambridge University officers' accessible via Research tools on the Janus Homepage (Cambridge University Library Catalogues), the Oxford Dictionary of National Biography (Online Edition, 2004-) and the Who was Who (Online Edition and printed volumes). Also, 
letters of correspondence on leaves of absence occasionally survived in the personnel files and in the minute books of the General Board.

${ }^{20}$ Barnett, Phipps, Academic travel, 5-7.

${ }^{21}$ See, for example, J. Ben-David, Centres of Learning: Britain, France, Germany, United States, New Brunswick, 1992; E. Crawford, Nationalism and Internationalism in Science, 1880-1939: Four Studies of the Nobel Population, Cambridge, 1992; Crawford, Shinn and Sörlin (Eds), Denationalizing Science.

${ }^{22}$ In the early 1950s, Cambridge academics rarely flew but went to the United States and other places by sea. In fact, 'the number of passengers that travelled by air over [the Atlantic Ocean] first exceeded the number that travelled by sea' in 1958. The same year saw the world's first scheduled transatlantic flights, resulting in fundamentally changing patterns of geographical mobility. D. Beaty, The Water Jump: The Story of Transatlantic Flight, 1976, London, 241-243; see also P.J. Rimmer and S.M. Davenport, The geographer as itinerant: Peter Scott in flight, 1952-1996, Australian Geographical Studies 36 (1998), 123-142, 125. I am grateful to Lucy C.S. Budd for pointing me to this literature.

${ }^{23}$ Crawford, Nationalism and Internationalism in Science, 28-78; Crawford, Shinn and Sörlin, The nationalization and denationalization of the sciences: an introductory essay, in Crawford, Shinn and Sörlin (Eds), Denationalizing Science, 1-42.

${ }^{24}$ Clark, Academic Charisma and the Origins of the Research University, 458. Brooke, A History of the University of Cambridge, 20-24, 515f. See also Brian Harrison (Ed.), The History of the University of Oxford: Vol. VIII - The Twentieth Century (Oxford: Clarendon Press, 1994).

${ }^{25}$ Cambridge colleges were required 'to give funds for university lectureships and chairs' from 1882 onwards. Clark, Academic Charisma and the Origins of the Research University, 459; J. Darwin, The growth of an international university, in J. Prest (Ed.), The Illustrated History of Oxford University, Oxford, 1993, 336-370, 357.

${ }^{26}$ According to William Clark, 'the modern era began, academically and belatedly, with the appointment of the Graham Commission as royal visitor to Oxford and Cambridge in 1850' but the resistance to the work of the commission was particularly strong at Cambridge. Even in 1872/73, the 
Master of Sidney Sussex 'might still accuse the reformers of drawing their inspiration from German universities', arguing that 'the university's only function was to conduct examinations, and that all teaching, including the support of laboratories, could be managed by the colleges'. See Clark, Academic Charisma and the Origins of the Research University, 457f.

${ }^{27}$ M. Authier, Zeittafel, in M. Serres (Ed.), Elemente einer Geschichte der Wissenschaften, Frankfurt a. M., 1998, 946-1030.

${ }^{28}$ Cambridge University's academic year is divided into three terms of slightly varying length, namely Michaelmas (October to December), Lent (January to March) and Easter (April to June). The Long Vacation usually lasts from July to September. Residence was obligatory in about three fourth of each term, i.e. in roughly 45 out of 60 days (the Easter term being a bit shorter). See Statute B.XI.2 in University of Cambridge (Eds), Statutes of the University of Cambridge with some Acts of Parliament relating to the University, Cambridge, 1882, 61.

${ }^{29}$ Keeping residence meant either A) living 'within one mile and a half of Great St. Mary's Church' and being 'not habitually absent from home more than two nights in the week, or B) [being] domiciled within five miles of Great St. Mary's Church and habitually [spending] in Cambridge at least two hours between eight o'clock A.M. and six o'clock P.M. in each of five days in the week, and at least fifteen hours in the week on the whole', while being 'reasonably accessible at stated times on at least three days in the week.' From the academic year 1885/86 onwards, professors and readers had to send residence returns to the General Board every term, notifying A) absences from home for more than two nights or B) the weeks in which he or she had not spent in Cambridge the required hours. The General Board of Studies was authorised to 'grant to any Professor or Reader leave to substitute for the residence required of him, in any one term or any part of it, residence for an equal time between July 1 and August 31, provided that the General Board of Studies are of opinion that such leave may be granted without prejudice to the interests of the University'. The Board was also prepared to 'grant occasional leave of absence for a period not exceeding one term on account of illness or other sufficient special cause on such conditions, if any, as they may think fit'. Cambridge University Reporter, 23 June 1885, 931, Grace No. 4; Draft, for the General Board of Studies, 22 February 1886, 
Cambridge University Archives (hereafter CUA) General Board of Studies (hereafter GB) Min III.1, 109.

${ }^{30}$ This applies to journeys of those academics that had to apply for leave of absence during full term time. Before 1926 these were professors and readers; from 1926 onwards it included all Cambridge University Teaching Officers.

${ }^{31}$ C. Good (Ed.), Dictionary of Education, New York, 1959, 424; see also W.C. Eells, The origin and early history of sabbatical leave, Bulletin, American Association of University Professors XLVIII (1962) 253-256, 253; C. M. Sima, The role and benefits of the sabbatical leave in faculty development and satisfaction, New Directions for Institutional Research 105 (2000), 67-75, 68f.; B. Kang, M.T. Miller, An overview of the sabbatical leave in higher education: a synopsis of the literature base, ERIC Document Reproductive Service No. ED 430 471, 1999.

${ }^{32}$ K.J. Zahorski, The Sabbatical Mentor: A Practical Guide to Successful Sabbaticals, Bolton, Mass., 1994,8 .

${ }^{33}$ Eells, The origin and early history of sabbatical leave, 253; Sima, The role and benefits of the sabbatical leave, 73 .

${ }^{34}$ Letter from Barnes to Mathison, 12 October 1912, CUA GB Min. III.2, 264.

${ }^{35}$ Letter from Burkitt to Barnes, 20 October 1912, CUA GB Min III.2, 264.

${ }^{36}$ Eells, The origin and early history of sabbatical leave, 254.

${ }^{37}$ Letter from Barnes to Mathison, 21 October 1912, CUA GB Min III.2, 264.

${ }^{38}$ See, for example, M. Heffernan, Geography, cartography and military intelligence: the Royal Geographical Society and the First World War, Transactions of the Institute of British Geographers 21 (1996) 504-533; T.J. Barnes, Geographical intelligence: American geographers and research and analysis in the Office of Strategic Services 1941-1945, Journal of Historical Geography 32 (2006) $149-168$.

${ }^{39}$ Minutes of proceedings at a meeting of the General Board of Studies (hereafter Minutes), 15 May 1918, CUA GB Min III.3, 61.

${ }^{40}$ On Ridgeway, see Brooke, A History of the University of Cambridge, 205. 
${ }^{41}$ Minutes, 29 May 1918, CUA GB Min III.3, 63.

${ }^{42}$ Minutes, 1 June 1921, CUA GB Min III.3, 157.

${ }^{43}$ Minutes, 15 June 1921, CUA GB Min III.3, 159.

${ }^{44}$ In special circumstances that exceeded the regulations and thus the competence of the General Board, the Council of the Senate was asked to sanction a 'Grace'. This was a particular frequent procedure during World War One. Between September 1939 and October 1947 Emergency Statutes were in place that empowered the General Board to grant leave of absence for so long as the applicant was engaged in national service.

${ }^{45}$ Eells, The origin and early history of sabbatical leave; W.C. Eells, E.V. Hollis, Sabbatical Leave in American Higher Education: Origin, Early History and Current Practices, Washington, 1962.

${ }^{46}$ The Registrary of the University (Ed.), Statutes of the University of Cambridge and Passages from Acts of Parliament Relating to the University, Cambridge, 1928, 40-41.

${ }^{47}$ In these cases, the respective term counted as term of service for the 'sabbatical' leave if the period of absence did not exceed the greater part of that term.

${ }^{48}$ See Statute D.XII.1 in The Registrary of the University, Statutes of the University of Cambridge, 4041; University of Cambridge (Ed.), Ordinances of the University of Cambridge: To 1 October 1955, Cambridge, 1955, 32, 399.

${ }^{49}$ Brooke, A History of the University of Cambridge, chapter 11.

${ }^{50}$ Brooke, A History of the University of Cambridge, 352.

${ }^{51}$ Brooke, A History of the University of Cambridge, 354.

${ }^{52}$ E. Crawford, Nationalism and Internationalism in Science, 38-43, 61-64; See also Crawford, Shinn, Sörlin, The nationalization and denationalization of the sciences; 13-21; F.S.L. Lyons, Internationalism in Europe, 1815-1914, Leyden, 1963; M.H. Geyer, J. Paulmann (Eds), The Mechanics of Internationalism, Oxford, 2001.

${ }^{53}$ On 23 April 1940, out of 42 University Teaching Officers aged between twenty-five and thirty years of age, 18 were engaged in national service. Eleven more were liable for military service, while 13 academics were reserved in other occupations. Minutes, 24 April 1940, CUA GB 160, Box 302, 184. 
${ }^{54}$ Note of 4 June 1940, CUA, Personnel file of Edgar Douglas Adrian.

${ }^{55}$ The British Council also inquired at Oxford University whether Needham, who worked at Gonville and Caius College, Cambridge, should convey an official address of greetings to the Academia Sinica on their behalf. They were 'sure that the Academia Sinica would be profoundly honoured and encouraged by such a communication, and that this act would contribute most valuably to the strengthening of the cultural relations and understanding between the two countries.' Letter from the British Council to Sir David Ross, Vice-Chancellor of Oxford University, 15 July 1942, Oxford University Archives UR6/HD/1, Honorary Degrees General, File 1.

${ }^{56}$ Joseph Needham became the first person ever to be elected to both the Royal Society (1941) and the British Academy (1971) on the basis of separate bodies of work in the natural sciences and in the humanities. G. Blue, Joseph Needham, in P. Harman, S. Mitton (Eds), Cambridge Scientific Minds, Cambridge, 2002, 299-312, 305-307.

${ }^{57}$ Minutes, 28 September 1944, 15 November 1944, CUA GB 160, Box 303, 2, 47.

${ }^{58}$ Minutes, 6 March 1946, CUA GB 160, Box 303, 182.

${ }^{59}$ According to Celina Sima, it has been reported that the number of professors on sabbatical in a given year hovers around 5\% at public universities in the United States, while it may reach $20 \%$ at private elite institutions (1990s). Sima, The role and benefits of the sabbatical leave, 70 .

${ }^{60}$ The remaining $4 \%$ of applications did not state a period of absence or left the period open. The differentiation of short-term, medium-term and long-term absences aims to provide the bigger picture. It seems to be impossible to find coherent categories for a period of 70 years that was characterised by rapid changes in transport and communication. Also, the period of absence may have been longer than stated in the application when the leave of absence preceded or followed vacations.

${ }^{61}$ In the context of the professionalisation of the application process after 1926, cancellations of granted academic leaves were recorded in the minutes as these involved changes in the applicants' rights on sabbatical leaves. Based on this information, it can be assumed that about $5 \%$ of the granted academic leaves were cancelled (whole period: 4.6\%; post-war period: $4.9 \%$ ). 
${ }^{62}$ These figures refer to the minimum as the destination of $15.9 \%$ of all academic leaves was not specified. The data shows that at least $2.7 \%$ of all academic leaves were only spent in Cambridge.

${ }^{63}$ Minutes, 4 December 1901, CUA GB Min III.2, 7.

${ }^{64}$ Minutes, 10 May 1916, CUA GB Min III.3, 15.

${ }^{65}$ Clark, Academic Charisma and the Origins of the Research University, 449.

${ }^{66}$ Clark, Academic Charisma and the Origins of the Research University, 463.

${ }^{67}$ L.M. Gelber, The Rise of Anglo-American Friendship: A Study in World Politics, 1898-1906, London, 1938, 1.

${ }^{68}$ Clark, Academic Charisma and the Origins of the Research University, 463.

${ }^{69}$ William Clark noted that '[i]n the 1880 s, contemporaries [in Britain] sensed a revolution was taking place. Every university of importance, it was said, must have facilities for science.' Clark, Academic Charisma and the Origins of the Research University, 459.

${ }^{70}$ See also P.J. Taylor, M. Hoyler, D.M. Evans, A geohistorical study of the rise of modern science: career paths of leading scientists in scientific networks, GaWC Research Bulletin (2007), who find no major linkages between German and English universities during the early nineteenth century in their analysis of the career paths of European academics.

${ }^{71}$ According to Heffernan's work on the Service de Mission between 1870 and 1914, about 'a third of all post-1870 missions involved either a colonial or an Eastern Mediterranean destination'. Heffernan, A state scholarship, 34, see also 28-29 and the comparable figures in table 1 of this paper.

${ }^{72}$ In the academic years $1885 / 86$ to $1954 / 55$, the ten most important countries for academic travel from Cambridge University were the United States (27.9\%), Great Britain (10.7\%; Ireland: 1.0\%), France (4.5\%), Germany (4.2\%), India (3.4\%), Canada (3.0\%), Italy (3.0\%), Australia (2.6\%), Switzerland (2.0\%) and the Netherlands (1.7\%).

${ }^{73}$ Minutes, 11 February 1925, CUA GB Min III.4, 18. On the role of Rutherford for the mutual stimulation of Cambridge science and settler physics in the British dominions, see K. Dean, Inscribing settler science: Ernest Rutherford, Thomas Laby and the making of careers in physics, History of Science 41 (2003) 217-240; Dean, Settler Physics in Australia and Cambridge. 
${ }^{74}$ Minutes, 13 February 1924, CUA GB Min III.4, 7.

${ }^{75}$ The first two categories were dominated by sabbatical leaves, while the last three mainly comprised additional leaves. The remaining $8.2 \%$ account for unspecified sabbatical leaves.

${ }^{76}$ Latour, Science in Action, 224-225.

${ }^{77}$ While the idea of scientific centres of calculation has been widely debated, developed and criticised by geographers, this study offers an opportunity to explore empirically the types and geographies of those circulatory flows constitutive of a particular scientific centre of calculation. For related geographical studies, see M. Bravo, Ethnographic navigation and the geographical gift, in D. Livingstone, C. Withers (Eds), Geography and Enlightenment, Chicago, 1999, 199-235; D. Gregory, Cultures of travel and spatial formations of knowledge, Erdkunde 54 (2000) 297-319, 316-317; M. Heffernan, Mars and Minerva: centres of geographical calculation in an age of Total War, Erdkunde 54 (2000) 320-333; Barnes, Geographical intelligence.

${ }^{78}$ Three applications came from John William Barker, Lecturer in Spanish. After his first planned stay as a visiting professor in Spain had been cancelled in 1931, he was asked by the British Council to act as their Assistant Representative in this country in the academic years 1944/45 and 1945/46. Another application was made by Charles Seltman, Lecturer in Classics, who wanted to participate in an exchange of staff between the Universities of Paris and Cambridge in the Easter term of 1940. Finally, Bryan Earle King, Lecturer in Law, applied for a visiting appointment in a German University during the academic year 1948/49, but since the Foreign Office was unable to arrange this for him, his dispensation was cancelled and replaced by an unspecified sabbatical leave. The planned visiting appointments on the continent were thus primarily related to wartime circumstances and their corollaries. On Barker, see Minutes, 29 April 1931, CUA GB Min III.6, 121a; 28 September 1944, 11 October 1944, 16 May 1945, CUA GB 160, Box 303, 4, 10, 196. On Seltman, see Minutes, 24 April 1940, CUA GB 160, Box 302, 180. On King, see Minutes, 28 July 1948, CUA GB 160, Box 304, 312; 12 January 1949, CUA GB 160, Box 305, 96.

${ }^{79}$ R. von Gizycki, The Associations for the Advancement of Science: An international comparative study, Zeitschrift für Soziologie 8 (1979), 28-49; P. Robertson, Coming of age: the British Association 
in Australia, 1914, The Australian Physicist (1980) 23-27; R. MacLeod, P. Collins (Eds), The Parliament of Science: The British Association for the Advancement of Science, 1831-1981, Northwood, 1981; see also C.W.J. Withers, D. Finnegan, R. Higgitt, Geography's other histories? Geography and science in the British Association for the Advancement of Science, 1831-c.1933, Transactions, Institute of British Geographers 31 (2006), 433-451.

${ }^{80}$ J. Vaughan, 'A certain idea of Britain': British cultural diplomacy and the Middle East, 1945-1957, Contemporary British History 19 (2005) 151-168, 152.

${ }^{81}$ MacLeod, Passages in imperial science, 117-150, 136-140.

${ }^{82}$ Minutes, 13 November 1946, CUA GB 160, Box 304, 61; 8 October 1947, 15 October 1947, CUA GB 160, Box 304, 6, 18.

${ }^{83}$ Minutes, 26 November 1952, CUA GB 160, Box 307, 69.

${ }^{84}$ Bell, Butlin and Heffernan stressed that both modern European science and European imperialism 'were supremely ambitious, universalising projects concerned to know all, to understand all and, by implication, to control all'. Bell, Butlin and Heffernan, Introduction, in Bell, Butlin and Heffernan (Eds), Geography and Imperialism, 1820-1940, 3.

${ }^{85}$ Based on the intervention of Needham and others, 'UNECO (the United Nations Education and Cultural Organization) became Unesco with the "S" standing for Scientific.' Needham headed the Science Division from 1946 to 1948. Crawford, Shinn, Sörlin, The nationalization and denationalization of the sciences, 24; Blue, Joseph Needham, 306. On Needham, see also Minutes, 24 April 1946, 11 June 1947, CUA GB 160, Box 303, 206, 304; 8 October 1947, 28 July 1948, CUA GB 160, Box 304, 7, 312; and Blue, Joseph Needham, 305-306.

${ }^{86}$ P. Bourdieu: The forms of capital, in J.G. Richardson (Ed.), Handbook of Theory and Research for the Sociology of Education, New York, 1986, 241-258. See also J. Painter, Pierre Bourdieu, in M. Crang, N. Thrift (Eds), Thinking Space, London, 2000, 239-259.

${ }^{87}$ D. Gregory, The geographical discourse of modernity, in D. Gregory, Explorations in Critical Human Geography, Heidelberg, 1998, 45-67, 57-58. 
${ }^{88}$ D.S. Lux, H.J. Cook, Closed circles or open networks?: Communicating at a distance during the scientific revolution, History of Science 36 (1998) 179-211, 211.

${ }^{89}$ In the context of the twentieth-first century, it can be assumed that increasing academic travel from and to China contributes to the emergence of a new apex of knowledge production centres. L. Leydesdorff and P. Zhou, Are the contributions of China and Korea upsetting the world system of science?, Scientometrics 63 (2005) 617-630; H. Jöns, Transnational mobility and the spaces of knowledge production: a comparison of global patterns, motivations and collaborations in different academic fields, Social Geography 2 (2007) 97-114, 103. 